\title{
Visualisation by vital staining with trypan blue of wounds punctured by Varroa destructor mites in pupae of the honey bee (Apis mellifera)
}

\author{
Ghazwan KANBAR, Wolf ENGELS* \\ Zoologisches Institut der Universität Tübingen, Auf der Morgenstelle 28, 72076 Tübingen, Germany
}

(Received 16 December 2002; revised 31 March 2003; accepted 20 June 2003)

\begin{abstract}
After invading a honey bee brood cell shortly before capping, female Varroa destructor mites puncture the integument of the host bee in order to suck haemolymph. The perforations used as feeding sites are difficult to detect. We developed a method of vital staining with trypan blue to visualise the wounds. The dye is taken up by damaged epidermal cells in the margin of repeatedly used punctures. This new coloration method allows localisation of wounds in prepupal and especially in all pupal stages of workers and of drones, but the staining failed in early postfeeding 5th instar larvae. The low-cost method is easy to use. Because secondary infestations by viral and bacterial pathogens are assumed to enter the bees through these wounds, the trypan blue method may be useful in studies on parasite-host relations, especially concerning vector functions. Since pupae survive the vital staining without apparent harm, they can be used subsequently for other investigations.
\end{abstract}

Apis mellifera / Varroa destructor / pupal infestation / integumental puncture / vital staining / trypan blue

\section{INTRODUCTION}

Reproduction of Varroa destructor (Anderson and Trueman, 2000) mites takes place only in capped brood cells of honey bees (Ifantidis and Rosenkranz, 1988). Oogenesis and subsequent oviposition depend on repeated haemolymph meals taken by female mites, beginning shortly after capping of the brood cell (Steiner et al., 1994; Garrido et al., 2000). For this purpose, the mites perforate the integument of the host bee. Little is known about the timing and location of the perforations, and how many wounds a host bee suffers during the 5th larval instar, prepupal and pupal stages. In addition, the number of punctures may vary depending upon the degree of infestation of a particular brood cell, and also on the number and stage of the $V$. destructor nymphs therein. However, haemo- lymph sucking by reproducing female mites and their progeny is not easy to observe in the closed environment of sealed host brood (Donzé and Guerin, 1994). Furthermore, even after opening of the cell and removal of the larva or pupa, wounds are difficult to detect especially in the white skin prior to pupal tanning. Means to visualise the punctures have not yet been described, and the localisation of the feeding sites without direct observation of sucking mites is extremely difficult.

Perforation by the chelicerae of the mite causes damage of host tissue in and around the wound. This damage affects the permeability of the epidermal cell membranes. Molecules normally unable to pass such barriers because of their size will enter into the cytoplasm. Trypan blue is known to enter stressed cells, thus indicating reduced vitality (Roche, 1999).

* Corresponding author: wolf.engels@uni-tuebingen.de 
Table I. Composition of the media used for trypan blue vital staining of integumental wounds made by Varroa destructor in preimaginal stages of honey bees.

\begin{tabular}{lc}
\hline Ringer solution & $5.00 \mathrm{~g} \mathrm{NaCl}$ \\
& $0.42 \mathrm{~g} \mathrm{KCl}$ \\
$0.25 \mathrm{~g} \mathrm{CaCl}_{2}$ \\
$1 \mathrm{~L}$ distilled water \\
\hline Vital staining medium & $100 \mathrm{~mL}$ Ringer solution \\
& $0.01 \mathrm{~g}$ Trypan blue \\
& adjusted to $\mathrm{pH} 6.8$ with \\
KOH $(0.1 \mathrm{M})$
\end{tabular}

The dye has a molecular weight of 1150 Dalton and is used to distinguish damaged from undamaged living cells. We tested if, using vital staining with trypan blue, the punctures made by haemolymph sucking $V$. destructor could be visualised in the integument of immature stages of honey bees sampled from infested capped brood cells.

\section{MATERIALS AND METHODS}

Sealed brood cells from combs taken from Apis mellifera colonies in the apiary of the University of Tübingen were uncapped and hosts infested by female mites of $V$. destructor were removed. The age in days after oviposition of the host bees was estimated according to the state of external differentiation and eye and cuticle coloration. For the vital staining, an incubation medium (Tab. I) consisting of insect ringer solution adjusted to $\mathrm{pH}$
6.8 was prepared and Trypan blue dye (crystalline 1 F 577; Chroma, Stuttgart, Germany) was added. Live prepupae and pupae were sampled and immediately vital stained at room temperature by emerging them for $30 \mathrm{~min}$ into $10-20 \mathrm{~mL}$ of medium, followed by a $3 \mathrm{~min}$ rinse in ringer without dye. Controls were incubated in dye-free ringer. This protocol was the result of experiments under varying conditions (dye concentration, duration of staining, addition of PIPES buffer; there was little effect on the coloration, but lower concentrations required prolonged incubation) and provided a distinct blue coloration of wounds in all preimaginal stages (Figs. 1, 2 and 3). Not only mitemade punctures but also any lesions in the integument of the bees became stained, because trypan blue penetrates the membranes of any cells with reduced vitality (Roche, 1999). The vital stained host bees were inspected under a photostereo microscope at up to $100 \times$ magnification, and the visualised wounds were photographed.

\section{RESULTS}

In early postfeeding and spinning 5th instar larvae, the punctures did not become well stained by trypan blue. Only from the transitional phase to the prepupa could the haemolymph sucking sites be visualised as blue spots (Fig. 1). In all pupal stages of workers and drones, the integumental wounds could be easily detected by the trypan blue vital staining procedure (Fig. 2). This result was reproducible in our studies over the last years, with bee brood collected from hives kept in various apiaries and also from colonies housed in a flight

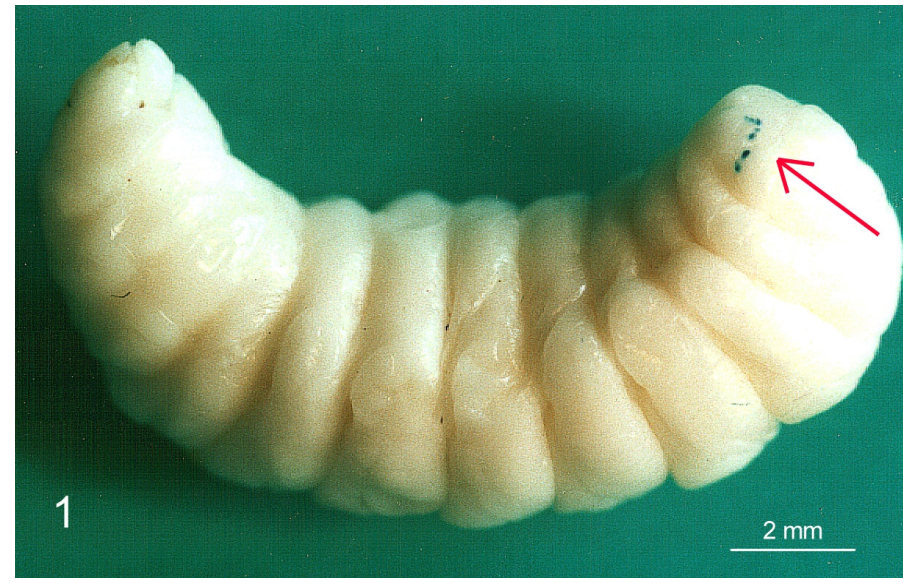

Figure 1. Live drone honey bee, transition from late post-feeding to prepupal 5th instar, with several trypan blue-stained punctures in the last abdominal segments (arrow) caused by a female Varroa destructor mite. 


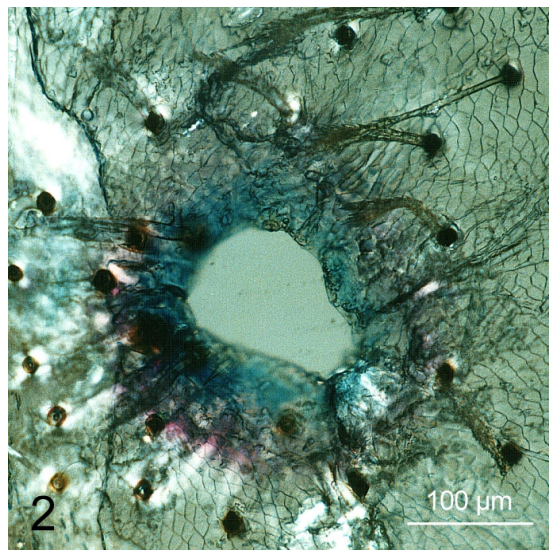

Figure 2. Integumental wound on the ventral side of the 2nd abdominal segment of a pharate adult drone honey bee, showing damaged cells around the wound margin which are vital stained by trypan blue. Notice that the cuticle and the growing hairs remained unstained. room during the winter. After carefully uncapping sealed brood cells, the mites could be seen on the body of the host bee. In contrast to the late larval stages, we then often observed adult female (Fig. 3) and nymphal mites sucking at the perforations on pupae.

The blue margin of the wound contrasts in particular with the white skin of late larval/ prepupal and early pupal stages (Fig. 1). Also, in later pupal phases, the then enlarged puncture is easy to localise as a blue spot (Figs. 2 and 3). As seen under higher magnification, the damaged cells surrounding the perforation become filled with trypan blue dye (Fig. 2). The cuticle (Fig. 3) and also, in pharate adults, the developing hairs remain uncoloured (Fig. 2).

Any integumental lesion of preimaginal stages becomes clearly visible by trypan blue staining as long as damaged epidermal cells can be seen through the transparent cuticle before tanning begins. Such damage may occur as a consequence of experimental removal of a

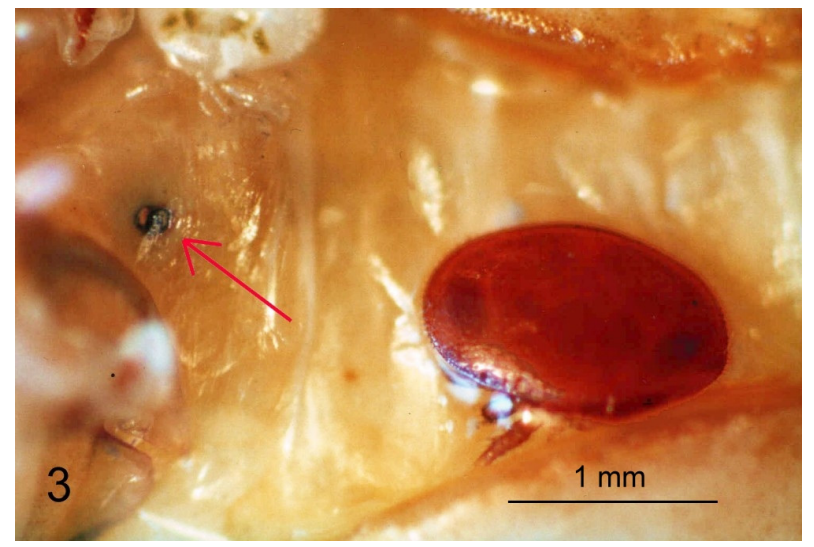

Figure 3. An adult female Varroa destructor sucking haemolymph from a wound on the ventral side of a honey bee worker pupa 17-18 days old. A second trypan blue-stained perforation is seen nearby (arrow).

Table II. Sample of pupal honey bees collected during the summer from $V$. destructor-infested brood cells and incubated in vital staining medium in order to visualise mite-made perforations. In this record, given as an example of our numerous analyses, trypan blue-stained wounds were detected in $95.5 \%$ of the individuals. In this sample, two wounds were detected in about $10 \%$ of the double-infested and $20 \%$ of the triple-infested pupae.

\begin{tabular}{lcccc}
\hline \multirow{2}{*}{$\begin{array}{l}\text { Number of female } \\
\text { mites per brood cell }\end{array}$} & \multicolumn{2}{c}{ Infested drone pupae } & \multicolumn{2}{c}{ Infested worker pupae } \\
\cline { 2 - 5 } & cells inspected & hosts with stained wounds & cells inspected hosts with stained wounds \\
\hline 1 & 228 & 217 & 229 & 217 \\
2 & 61 & 60 & 23 & 22 \\
3 & 12 & 12 & 8 & 8 \\
\hline
\end{tabular}


host, of early and soft pupae from sealed brood cells, and was occasionally observed in the case of infested as well as uninfested hosts. In pupae, removed uninjured from capped brood cells containing no mites, only rarely a lesion was detected by the trypan blue staining. However, such lesions can usually be well distinguished from the round mite-made perforations.

The number of parasitic wounds detected on an individual bee depends on the stage and the level of parasitism of the capped brood cell, as shown by representative data for a single summer sample (Tab. II). In pupae, the perforations are found preferentially on the sternite of the 2 nd abdominal segment. This holds for $98-99 \%$ of the drones and ca. $75 \%$ of the workers which alternatively may have perforations in more lateral position on the thorax. Especially in the case of multiple infestations of the same cell (Tab. II), more than one wound may be found, in most cases close together on the 2nd abdominal sternite (Fig. 3). The maximum number, counted by inspecting over 3000 capped brood cells in the course of two years, was three wounds per pupa. This survey included all stages from white pupae to pharate adult bees.

\section{DISCUSSION}

The application of our new method of vital staining the punctures in the skin of live immature honey bees with trypan blue offers a promising measure for localising wounds made by $V$. destructor. The procedure can be recommended as a useful tool for all types of study where integumental perforations have to be detected, especially in prepupal and all pupal stages. Because of its ease in handling, fast results, and highly reliable detection of wounds used as feeding sites by haemolymphsucking mites in their reproductive phase, our new method can be recommended for various purposes. In particular, this low-cost technique could be established in all laboratories involved in varroosis research on parasite-host relationships (Garrido et al., 2000, 2001). An important advantage is that the vital staining seemed to cause no harm to the pupae as they survived and could develop into imagoes and, therefore, be used for subsequent experiments and analyses.
The assumed vector role of $V$. destructor in the transmission of viral and bacterial diseases (Brødsgaard et al., 2000) demands more detailed investigation of when and how such secondary infestations occur through the openings of the pupal bee body surface provided by the mite-made wounds. We already observed colonies of the European foulbrood agent Melissococcus pluton in punctures of the pupal integument, indicating perhaps another pathway of pathogen transfer (Kanbar et al., 2002). Since the total number of detected perforations did not increase in the course of pupal development, we conclude that female mites puncture their host bee only at the very beginning of the pupal phase. Later on, the mother mites and all their progeny evidently repeatedly use the same feeding sites (Donzé and Guerin, 1997). Therefore, the wounds remain open throughout the pupal stage, thus providing a long period for unhindered passage of pathogens.

\section{ACKNOWLEDGEMENTS}

We like to thank Robert Paxton for critical reading of the manuscript and Imkermeister Andreas Oelkrug for skillfull rearing of the bees.

Résumé - Visualisation par coloration vitale au bleu de trypane des piqûres faites par les acariens Varroa destructor aux nymphes d'abeilles domestiques Apis mellifera. Après avoir pénétré dans une cellule de couvain peu avant l'operculation, la femelle de Varroa destructor transperce la peau de son hôte pour en sucer l'hémolymphe. Il est difficile de détecter les piqûres qui ont servi à la prise de nourriture. Nous avons mis au point une méthode de coloration vitale au bleu de trypane (Tab. I) qui permet de rendre ces piqûres visibles (Fig. 1). Le colorant est incorporé dans les cellules épithéliales lésées du pourtour des piqûres fréquemment utilisées. Grâce à cette nouvelle méthode de coloration, il est possible de localiser de façon irréprochable les piqûres sur les prénymphes et en particulier sur les nymphes d'ouvrières et de mâles (Fig. 3) de tous stades. Chez les nymphes pluri-parasitées, on peut détecter deux piqûres (Tab. II). Par contre, la coloration ne fonctionne pas chez les larves du $5^{\mathrm{e}}$ stade qui ont fini de se nourrir et qui commencent à filer. La coloration vitale est simple à exécuter et peu coûteuse. Parce qu'on suppose que les virus et bactéries peuvent atteindre les abeilles par ces blessures lors des infections secondaires, nous proposons d'introduire cette méthode au bleu de trypane en particulier dans les recherches sur les relations hôtes-parasites, dans lesquelles le rôle de 
V. destructor comme vecteur d'infections pour les nymphes d'abeilles a été prouvé. Puisque les nymphes survivent sans dommages à la coloration, elles peuvent être utilisées pour d'autres recherches.

Varroa destructor / nymphe d'abeille / infection / piqûre / coloration vitale / bleu de trypane

Zusammenfassung - Sichtbarmachen von durch Varroa destructor verursachten Stichwunden an Puppen der Honigbiene (Apis mellifera) durch Vitalfärbung mit Trypanblau. Nachdem ein Varroa-Weibchen kurz vor der Verdeckelung in eine Honigbienen-Brutzelle eingedrungen ist, durchsticht es die Haut seiner Wirtsbiene, um Haemolymphe zu saugen. Es ist schwierig, die zur Nahrungsaufnahme benutzten Stichwunden zu entdecken. Wir entwickelten eine Methode der Vitalfärbung mit Trypanblau (Tab. I), um die Stichwunden sichtbar zu machen (Abb. 1). Der Farbstoff wird von den durch häufiges Saugen geschädigten Epidermiszellen des Wundrandes aufgenommen (Abb. 2). Mit der neuen Färbemethode können die Stichwunden an Vorpuppen und insbesondere an Arbeiterinnen- und Drohnen-Puppen (Abb. 3) aller Stadien einwandfrei lokalisiert werden. Bei mehrfach-parasitierten Puppen kommen auch 2 Stichwunden vor (Tab. II). Das Anfärben funktionierte dagegen bei frühen Freßmaden des 5. Larvenstadiums nicht. Die Vitalfärbung ist einfach und kostengünstig durchzuführen. Weil vermutet wird, daß bei Sekundärinfektionen Viren und Bakterien durch diese Wunden in die Bienen gelangen, wird vorgeschlagen, die neue Trypanblau-Methode insbesondere bei solchen Untersuchungen über Parasit-WirtBeziehungen einzusetzen, in denen die Rolle von Varroa-Milben als Überträger von Infektionen der Bienen-Puppen geprüft werden soll. Da sie eine Vital-Färbung unbeschadet überleben, stehen die Puppen zudem für anschließende Untersuchungen zur Verfügung.

\section{Apis mellifera / Varroa destructor / Infektion von Puppen / Stichwunden / Vitalfärbung / Trypanblau}

\section{REFERENCES}

Anderson D.L., Trueman J.W.H. (2000) Varroa jacobsoni (Acari: Varroidae) is more than one species, Exp. Appl. Acarol. 24, 165-189.

Brødsgaard C.J., Ritter W., Hansen H., Brødsgaard H.F. (2000) Interactions among Varroa jacobsoni mites, acute paralysis virus, and Paenibacillus larvae larvae and their influence on mortality of larval honeybees in vitro, Apidologie 31, 543554.

Donzé G., Guerin P.M. (1994) Behavioral attributes and parental care of Varroa mites parasitizing honey bee brood, Behav. Ecol. Sociobiol. 34, 305-319.

Donzé G., Guerin P.M. (1997) Time-activity budgets and space structuring by the different life stages of Varroa jacobsoni in capped brood of the honey bee, Apis mellifera, J. Insect Behav. 10, 371-393.

Garrido C., Rosenkranz P., Stürmer M., Rübsam R., Büning J. (2000) Toluidine blue staining as a rapid measure for initiation of oocyte growth and fertility in Varroa jacobsoni Oud., Apidologie 31, 559-566.

Garrido C., Paxton R., Rosenkranz P. (2001) VarroaReproduktion: Wirtsfaktoren oder Eigenschaften des Parasiten? Apidologie 32, 481-482.

Ifantidis M.D., Rosenkranz P. (1988) Reproduktion der Bienenmilbe Varroa jacobsoni (Acarina: Varroidae), Entomol. Gen. 14, 111-122.

Kanbar G., Engels W., Winkelmann G. (2002) Übertragen Varroa-Milben auch Faulbrut (Melissococcus pluton)? Apidologie 33, 487-488.

Roche Lexikon Medizin, 4th ed. (1999) Trypanblau, engl. trypan blue, zur Vitalitätsprüfung, Urban \& Fischer Verlag, München.

Steiner J., Dittmann F., Rosenkranz P., Engels W. (1994) The first gonocycle of the parasitic mite (Varroa jacobsoni) in relation to preimaginal development of its host, the honey bee (Apis mellifera carnica), Invertebr. Reprod. Dev. 25, 175-183. 